THUFULI: Jurnal Pendidikan Islam Anak Usia Dini

Volume 2 Nomor 2 Tahun 2020

e-ISSN: $2685-161 \mathrm{X}$

\title{
PENGASUHAN ANAK USIA DINI DI ERA NEW NORMAL PERSPEKTIF ISLAM
}

\author{
Rosyida Nurul Anwar' ${ }^{1}$ Nurul Azizah ${ }^{2}$ \\ Universitas PGRI Madiun ${ }^{1}$, Universitas Wahid Hasyim Semarang ${ }^{2}$ \\ e-mail: 1rosyidanurul@unipma.ac.id, 2nuza_azizah@unwahas.ac.id
}

Diterima: 30 September 2020I Direvisi: 17 November 2020 I Disetujui: 18 November 2020 (C)2020 Pendidikan Guru Raudhatul Atfhal Fakultas Agama Islam Universitas Islam Malang

\begin{abstract}
Early childhood activities in the new normal era change all habits in fulfilling children's rights which are usually done on normal days. Caring for children in the new normal era not only provides a sense of comfort and avoids children from deviant behavior, but parents are required to pay attention to children's health and safety activities so that they avoid exposure to viruses. The purpose of this study is to describe how Islam manages parents in raising children in the new normal era. The research method uses a literature study. The results showed that Islam regulates that in parenting children must involve the scope of faith, morals, worship, and muamalah. Parenting patterns are adjusted to the child's developmental stages. Caring for children in the new normal era is also carried out by providing programmed and continuous guidance as well as mentoring children at home so that children continue to get learning and children have strong characters, namely having praiseworthy behavior and having morals.
\end{abstract}

Kata Kunci: parenting, new normal, Islam

\section{A. Pendahuluan}

Situasi pandemi covid-19 pemerintah Indonesia meminta masyarakat untuk menjaga produktivitas dengan tatanan baru yang disebut new normal yakni melakukan aktivitas biasa dengan memperhatikan protokol kesehatan. Tatanan baru diperlukan sebab saat ini belum ditemukannya vaksin untuk mengobati covid19 (Tirto.id, 2020). Dampak yang timbul sebagai upaya mengendalikan pandemi pada sektor ekonomi, kegiatan sehari-hari, dan seluruh aspek kehidupan anak, dan dikhawatirkan dampak tersebut dapat melekat pada sebagian anak seumur hidup (UNICEF, 2020). Anak usia dini berdampak risiko kesehatan lebih rendah daripada kelompok usia lanjut (Ludvigsson, 2020). Covid-19 bukan virus pertama yang mengancam umat manusia, namun perlunya strategi efektif dalam memperkuat keluarga dengan merespon dan merawat serta melindungi masa depan anak-anak di dunia (Clark et al., 2020).

This work is licensed under Creative Commons Attribution Non Commercial 4.0 International License Available online on: http://riset.unisma.ac.id/index.php/fai/index 
Aktivitas anak usia dini di era new normal merubah seluruh kebiasaan dalam memenuhi hak-hak anak yang biasanya dilakukan dihari-hari normal. Pada era new normal, krisis pendidikan dan pembelajaran masih dirasakan oleh anak usia dini, 99 persen anak usia dini melakukan pembelajaran dirumah. Pandemi covid-19 secara tidak langsung mengembalikan anak-anak dari guru kepada orangtua tanpa bisa menolak karena pembelajaran di rumah melibatkan peran keluarga. Anak melihat dan mampu meniru daripada yang orangtuanya cerminkan pada anak dalam pengasuhannya, karena dalam keluarga terutama orangtua sebagai pengasuh utama pada anak. Apa yang dilakukan orang tua, otomatis akan terekam di otak anak, karena masa tersebut adalah masa-masa otak menyerap (Montessori, 2013). Terlebih jika anak bermain gadget berlebih, sangat tidak baik bagi kesehatan mental dan fisik anak, namun menurut (Sulyandari, 2019) jika penggunaan gadged diawasi, maka resiko tersebut akan berkurang.

Anak sebagai anugerah yang diberikan oleh Allah Swt, sebagai amanah bagi orangtua untuk dipelihara, dididik, dibina sehingga orangtua mampu mencetak anak yang berkualitas, memiliki ketahanan hidup serta kekuatan sebagai bekal dalam mengarungi kehidupannya dimasa yang akan datang (Ayun, 2016). Anak usia dini adalah makhluk Allah Swt yang sedang mengalami perkembangan fisik dan psikologis secara pesat (Juliani, 2012). Penanaman nilai-nilai agama pada anak diberikan melalui berbagai metode pembinaan yang tepat disetiap tahapan perkembangannya agar memaksimalkan anak menjadi muslim yang kaffah (Anwar \& Cristanti, 2019). Islam memiliki konsep yang jelas kepada orangtua dalam memberikan pendidikan dan pengasuhannya kepada anak.

Pengasuhan anak di era new normal tidak hanya pemberian rasa nyaman dan mengindarkan anak dari perilaku menyimpang dan menjadi Qurrota ayun saja akan tetapi orangtua diharuskan untuk memperhatikan aktivitas kesehatan dan keselamatan anak agar terhindar dari covid-19. Perkembangan sosial merupakan aspek perkembangan yang berkaitan dengan perilaku sosial sesuai dengan aturan norma sosial yang berlaku (Dewi, 2019). Penanaman akhlak dan pembentukan karakter pada anak dilakukan dengan kehangatan kasih sayang serta keterlibatan emosi antara anak dan orangtua. Penerapan protokol kesehatan pada anak dilakukan dengan disiplin serta penjelasan tentang aturan, reward dan punishment secara konsisten dan kelembutan kasih sayang. Pemenuhan kebutuhan fisik, kebutuhan psikologis dan sosialisasi norma-norma yang berlaku di masyarakat juga harus dilakukan orangtua dalam mengasuh anak di era new normal.

Banyak orangtua yang merasa bingung dan kerepotan dalam mengasuh dan mendidik anak di situasi new normal, terutama pada orangtua yang bekerja. Peran ganda dihadapi pada orangtua yang bekerja dari rumah. Peran ganda yang diemban 
dapat menjadi sumber stress bagi orangtua. Situasi covid-19 juga menyebabkan kekhawatiran pada orangtua terkait pendapatan yang berkurang bahkan hilang. Tekanan yang dimiliki orangtua dan ditambah dengan tugas mengasuh anak dan membantu anak belajar dirumah menimbulkan tingkat stress yang tidak biasa yang dapat berujung terjadinya kekerasan pada anak. Kekerasan yang dialami anak menimbulkan luka dan trauma pada anak yang berdampak pada kehidupan anak selanjutnya. Perilaku dan tindakan orangtua dapat mempengaruhi perkembangan anak yaitu pada aspek fisik dan psikis (spiritual) atau perilaku jasmani dan rohani. Orangtua perlu menciptakan kondisi yang menyenangkan dan mendidik dengan berperilaku sabar, tawakal, ihklas, tenang, bahagia dan tentram.

Tujuan penelitian ini adalah memberikan informasi dan mendeskripsikan bagaimana orangtua mengasuh anak usia dini di era new normal dalam perspektif Islam. Perilaku dan kesiapan orangtua dalam mengasuh anak di era new normal diperlukan agar anak mampu menjadi anak yang berakhlak, berkarakter kuat serta implementasi belajar anak di rumah dapat terlaksana.

\section{B. Metode}

Penelitian ini menggunakan metode penelitian kepustakaan (library research) yakni jenis penelitian kualitatif. Data-data dikumpulkan dan diperoleh dari bukubuku, artikel-artikel pada jurnal, dan berita. Penelitian dideskripsikan dengan menggambarkan hasil temuan melalui pengamatan, pencatatan dan penganalisian tentang permasalahan penelitian kemudian dipetakan hingga menjadi suatu pola yang utuh dan praktis.

\section{Hasil dan Pembahasan}

Proses alami terjadi pada pertumbuhan dan perkembangan anak usia dini mulai dari dalam kandungan hingga akhir hayat. Proses perkembangan manusia terdapat dalam al Quran. Ahli fiqh, Abu Zahrah yang dikutip oleh Khusni membagi empat fase tumbuh kembang anak yaitu ash-Shobiy (anak kecil), mumayyiz (mampu membedakan sesuatu), murabiq (mendekati usia baligh), baligh (mampu menerima hukum) (Khusni, 2018). Islam sesungguhnya telah memberikan isyarat pada konsepsi perkembangan tersebut yang menjadi bagian tak terpisahkan dalam tatanan hukum Islam.

Perkembangan manusia dari sudut pandang Islam, harus dilihat sebagai satu kesatuan yang utuh dan saling terkait. Artinya semua perkembangan baik fisik, mental, sosial, emosional tidak dapat dipisahkan dan memiliki keterikatan yang kuat (Hanafi, 2018). Islam mengajarkan bahwa dalam pengasuhan anak usia dini harus melibatkan ruang lingkup aqidah, akhlak, ibadah dan muamalah. Aspek-aspek 
yang harus dipersiapkan dalam mengasuh anak di era new normal meliputi afektif, kognitif dan behavioral dengan beradaptasi dengan masa pandemi.

Pengasuhan anak usia dini pada tiap-tiap orangtua memiliki berbagai macam cara. Asuhan orangtua sebagai suatu cara terbaik bagi orangtua dalam mendidik anaknya sebagai wujud rasa tanggung jawab terhadap anaknya. Hurlock dalam Sigit Setiawan membagi pola asuh menjadi tiga yaitu otoriter, demokratis, dan permisif (Setiawan, 2017).

Pertama, pola asuh otoriter adalah cara mengasuh dan mendidik anak sepenuhnya dikontrol oleh orangtua, peraturan ketat dan tidak memberikan ruang anak dalam menyampaikan keinginan, terkadang hukuman fisik akan terjadi bila anak tidak mampu memenuhi standar yang ditetapkan orangtua. Pada tipe ini orangtua tidak memerlukan umpan balik dari anak untuk memahami keinginan anak, tidak mengenal kompromi dan cenderung satu arah (Padjirin, 2016). Pola asuh otoriter sesungguhnya tidak sesuai dengan apa yang diajarkan dalam Islam, sebagaimana sabda Rasulullah Saw "barangsiapa tidak menyayangi, maka tidak disayang”(Muhammad Fu'ad Abdul, 2010). Pola asuh ini dapat pula menghambat perkembangan dan kreativitas anak. Pada situasi covid-19 dimana anak menghabiskan banyak waktu dirumah memiliki kebosanan maka naluri anak untuk bermain di luar rumah tidak dapat dibendung. Tak jarang orangtua dengan pola asuh otoriter melakukan tindakan pemaksaan dan penghukuman tanpa memberikan pengertian dengan kasihsayang dan kelembutan pada anak untuk menghentikan keinginan bermain diluar. Hal ini juga tidak sesuai dengan apa yang Allah perintahkan dalam menasihati yaitu bil hikmah.

Kedua, pola asuh demokratis merupakan pola asuh yang mengutamakan kepentingan anak, namun tidak sungkan untuk mengontrolnya. Orang tua dengan asuhan ini rasional, tidak berharap berlebihan yang melampaui kemampuan anak, lebih selalu mendasari tindakannya pada rasio atau pemikiran-pemikiran. Hal ini juga sesuai dengan prinsip Islam bersifat tidak memaksa bahkan dalam urusan aqidah sebagaimana QS. Al Baqarah ayat 256 yang artinya tidak ada paksaan dalam memeluk agama Islam. Pada era new normal tipe demokatis dilakukan dengan syarat orangtua memfasilitasi anak dengan berbagai alat perlindungan ketika ke luar rumah agar anak tetap dapat mengeksplor bakat dan kreativitasnya tanpa khawatir terpapar virus.

Ketiga, pola asuh permisif merupakan salah satu bentuk pola asuhyang memberikan kebebasan kepada anak semaksimal mungkin. Anak-anak tidak dituntut untuk bertangggung jawab dan orang tua tidak banyak mengontrol. Pola asuh ini menggunakan pendekatan yang sangat reseptif (mau mendengarkan) tetapi cenderung terlalu santai. Gunakan pendekatan yang sangat toleran untuk anak-anak 
dan orang tua relatif hangat dan menerima anak apa adanya. Pada pola asuh ini, kelonggaran dan toleransi kepada anak di era new normal harus dibarengi dengan pengetahuan orangtua bagaimana dapat cara berdamai dan beraktivitas dengan memperhatikan protokol kesehehatan agar terhindar dari covid-19.

Asuhan Islam merupakan bagian integral dari perilaku dan perlakuan orang tua terhadap anak kecil dengan cara membesarkan, mendidik, membina, membiasakan, dan membimbimbing anak secara optimal berdasarkan Al-Qur'an dan Sunnah Nabi Muhammad SAW. Islam sangat memperhatikan tahapan perkembangan anak pada setiap pola pengasuhan yaitu:

Pertama, pola asuh pada usia 0-6 tahun. Rasulullah Saw mencontohkan kepada orangtua untuk menyayangi, mengasihi serta memanjakan anak dengan tanpa terbatas. Masa krisis pandemic covid-19, pergaulan anak terbatas maka sebagai orangtua dapat meberikan kasih sayang lebih ekstra kepada anak agar anak merasa orangtua selalu ada disisi mereka dalam keadaan apapun.

Kedua, pola asuh pada usia 7-14 tahun. Pada tahap ini kedisiplinan dan tanggungjawab orangtua harus ditanamkan kepada anak. Kedisiplinan terhadap ibadah sudah mulai diterapkan sebagaimana hadist Rasulullah Saw "Perintahlah anak-anak kamu supaya mendirikan shalat ketika berusia tujuh tahun dan pukullah mereka karena meninggalkan shalat ketika berumur sepuluh tahun dan asingkanlah tempat tidur di antara mereka (lelaki dan perempuan)." Memukul tidak dimaksudkan untuk menyiksa, hanya untuk mengingatkan anak-anak. Pada era new normal pola kedisplinan juga ditanamkan pada anak untuk terbiasa membersihkan tangan memakai air dan sabun, memakai masker serta menjaga jarak dengan orang lain terutama pada orang yang sedang tidak sehat. Hal ini dilakukan semata-mata untuk anak agar lebih mandiri.

Ketiga, pola asuh usia 15-21 tahun. Pada tahap usia ini anak memasuki aqil baligh sehingga orantua memerlukan seni dalam membina hubungan dengan anak. Menjalin komunikasi dan menjadi pendengar yang baik dan setia menjadi salah satucara orangtua dekat dengan anak. Keempat, pola asuh anak usia 21 tahun keatas. Pada masa ini kepercayaan dari orangtua dibutuhkan oleh anak. Pada usia ini orangtua hanya dapat memantau dan mengarahkan anak. Nasehat merupakan cara efisien dalam mendidik anak pada tahapan ini.

Tujuan adanya pola asuh adalah untuk menhasilkan anak memiliki kompetensi-kompetensi tertentu. Pola asuh orangtua terjadi ketika orangtua berinteraksi dengan anak sehingga dalam pelaksnaannya orangtua haruslah cerdas dan kreatif untuk dapat mengetahui perkembangan dan mengasah anak. Kompetensi-kompetensi tersebut diantaranya adalah kompetensi aqidah dan 
Ketuhanan Yang Maha Esa, kompetensi akhlak (moral), kompetensi fisik, kompetensi motorik, kompetensi akademik, serta kompetensi sosial emosional.

Mengasuh anak memerlukan bimbingan dan pembinaan yang terarah dan terprogram secara berkesinambungan. Anak terlahir dengan fitrah kebaikan, dan untuk menjadikan anak memiliki kesholehan dengan bekal kefitrahannya tersebut maka bimbingan dan pembinaan yang terarah dan terprogram secara berkesinambungan diperlukan oelh orangtua kepada anak sebagai tanggungjawab. Prinsip membimbing anak pada dasarnya bertumpu pada tiga upaya, yaitu: memberi teladan, memelihara, dan pembiasaan.

Pertama, pemberian teladan orangtua kepada anak di era new normal diawali dengan memberikan contoh dalam menjaga kesehatan, kebersihan dan imunitas. Islam telah mengajarkan kepada umatnya untuk senantiasa menjadi muslim yang kuat dan sehat. Kesehatan merupakan bentuk rahmat yang besar sebagai modal dasar dalam kehidupan. Menjaga imunitas agar tidak tertular dengan covid-19 karena kunci utama menghadapi virus tersebut adalah dengan menjaga daya tahan tubuh, menjaga kebersihan dan kehalalan makanan. Pemberian teladan juga dengan senantiasa tetap melaksanakan amalan ibadah ditengah pandemi. Karakteristik anak usia dini adalah pandai meniru, apa yang dilakukan oleh orang-orang terdekat akan ia lihat dan ia amati untuk ia lakukan. Tindakan orangtua dalam berbicara, betutur kata lembut, dan perbuatan menjadi role model seorang anak sehingga selayaknya orantua memberikan contoh yang baik.

Kedua, memelihara dan merawat anak agar menjadi penerus dalam keluarga yang memiliki nilai-nilai Islam. Allah Swt memerintahkan manusia dalam QS.At Tahrim ayat 6 untuk memelihara diri dan dan keluarga dari api neraka, dalam hal ini di perintahkan untuk mencegah perbuatan yang munkar. Majunya teknologi dan mudahnya mencari informasi melalui internet menjadi celah yang berakibat penyimpangan akhlak bisa tidak ada iman. Ditengah pandemi covid-19 anak-anak lebih banyak menghabiskan waktu dirumah, tidak menutup kemungkinan anak akan mengakses informasi yang menyimpang bila orangtua tidak mengontrol.

Ketiga, pembiasaan merupakan perbuatan yang dilakukan diulang-ulang sehingga menjadi kebiasaan. Pembiasaan dalam hal ini baik berupa kebiasaan positif maupun negative. Membina agar anak memiliki sifat terpuji, tidak hanya dengan menjelaskan dan memahamkan anak saja, akan tetapi perlu membiasakan anak untuk melakukan hal-hal baik. Harapannya ketika membiasakan tersebut anak diharapkan akan memiliki sifat baik dan menghindari tercela. Latihan untuk membiasakan diri membuat anak cenderung berbuat baik dan meninggalkan keburukan. 
Pada era new normal, membimbing bersamaan dengan aktivitas mendampingi orang tua pada anak. Anak identik dengan dunia bermain, maka penting orangtua dalam mendampingi anak dalam bermain. Bermain menjadi cara anak dalam belajar, mengasah sosial emosi, dan bahasa. Maka peran mendampingi anak di masa ini perlu dilakukan denga ekstra untuk mencegah terpapar virus covid-19. Pemilihan tempat bermain yang aman jika telah bosan berada di rumah, mendampingi anak ketika anak bercampur baur bermain dnegan orang lain, mengawasi kegiatan bermain anak serta mengarahkan dengan berinteraksi dengan anak. Dalam hal mendampingi orangtua harus memahami kebutuhan anak dan membantu dengan imajinasi-imajinasi yang mampu mengasah perkembangan anak.

Perubahan rutinitas pagi hari di rumah yang tidak terjadwal seperti di sekolah sangat mungkin membuat anak-anak bingung, dan bisa jadi menghapus kebiasaan yang telah terbentuk. Kemandirian, tanggung jawab, kepedulian, dan keterampilan sosial emosional yang telah terbentuk selama ini dapat berkurang atau bahkan hilang karena kurangnya pemeliharaan perilaku di rumah. Pandemi covid-19 membuat banyak orangtua terutama ibu stres dikarnakan terlalu lama menghadapi anak dirumah, hal ini terjadi dikarenakan kultur masyarakat yang masih menganggap bahwa pendidikan anak masih berada "di sekolah".

Pendidikan karakter di era new normal dalam keluarga merupakan sebuah langkah orang tua kepada anak agar anak tumbuh dan menghayati nilai-nilai moral guna menyiapkan kehidupannya dan membentuk pribadi yang berakhlak mulia. Penguatan anak adalah penguatan perilaku terpuji pada anak. Nilai-nilai karakter yang perlu dikuatkan oleh orangtua di masa ini adalah karakter religious, jujur, peduli, disiplin, mandiri, toleran, cinta kebersihan dan lingkungan, cinta tanah air. Semua ini dapat dilaksanakan apabila tentunya orangtua memiliki karakter kuat pula dalam menyikapi ujian yang dihadapi saat ini. Tujuan penguatan karakter pada anak sesuai dengan misi kenabian yang dibawa oleh Muhammad Saw, yaitu sebagai seseorang yang diutus untuk menyempurnakan akhlak manusia (Anwar, Wardani, \& Vitriana, 2019).

\section{Simpulan}

Pengasuhan anak di era new normal tidak hanya pemberian rasa nyaman dan mengindarkan anak dari perilaku menyimpang dan menjadi Qurrota ayun saja akan tetapi orangtua diharuskan untuk memperhatikan aktivitas kesehatan dan keselamatan anak agar terhindar dari paparan virus covid-19. Islam memperhatikan dan mengajarkan bagaimana cara mengasuh anak yakni dengan menjadi anak yang beribadah pada Allah Swt dan menjadi khalifah fill ard meskipun dalam pelaksanaanya tiap-tiap orangtua memiliki pola asuh yang berbeda. 
Anak adalah aset orangtua di akhirat, maka untuk mendapatkan anak yang bermanfaat dan sholeh, orangtua yang dalam kesehariannya diharuskan memberikan teladan yang baik dan membangun kedekatan pada anak. Mengasuh anak juga menjadi bagian dari belajar sepanjang hayat bagi orangtua sebagaimana Islam menganjurkan untuk selalu belajar hingga nafas terakhir.

\section{Daftar Rujukan}

Anwar, R. N., \& Cristanti, Y. D. (2019). Peran Pendidikan Anak Perempuan Dalam Membentuk Masyarakat Madani. Jurnal Care, 6(2), 11-18.

Anwar, R. N., Wardani, L. A., \& Vitriana, U. (2019). Pengelolaan Masjid Kampus Sebagai Pusat Pendidikan Islam dalam Pembentukan Karakter Mahasiswa di Universitas PGRI Madiun. Tarlim: Jurnal Pendidikan Agama Islam, 2(2), 135140.

Ayun, Q. (2016). Dalam Membentuk Perkembangan Kepribadian Anak: Perspektif Psikologi Perkembangan Islam. Attarbiyah, 26, 91-118. https://doi.org/10.18326/attarbiyah.v26.91-118

Dewi, Mutiara sari. (2019). Profil Perkembangan Sosial Anak Kelompok B Dalam Bermain Peran. Jurnal Thufuli: Jurnal ilmiah pendidikan Anak Usia Dini. 1 (1) http://riset.unisma.ac.id/index.php/thufuli/article/view/2778/2596.

Clark, H., Coll-Seck, A. M., Banerjee, A., Peterson, S., Dalglish, S. L., Ameratunga, S., ... Costello, A. (2020). A Future for the World's Children? A WHO-UNICEF-Lancet Commission. The Lancet, 395(10224), 605-658. https://doi.org/10.1016/S0140-6736(19)32540-1

Hanafi, I. (2018). Perkembangan Manusia Dalam Tinjauan Psikologi Dan Alquran. $I Q$ (Ilmu Al-Qur'an): Jurnal Pendidikan Islam, 1(1), 84-99.

Juliani, P. (2012). Pola Asuh Dan Karakter Anak Dalam Perspektif Islam. Prosiding Seminar Nasional Psikologi Islam, 47-51.

Khusni, M. F. (2018). Fase Perkembangan Anak Dan Pola Pembinaannya Dalam Perspektif Islam. Martabat: Jurnal Perempuan Dan Anak, 2(2). https://doi.org/10.21274/martabat.2018.2.2.361-382

Ludvigsson, J. F. (2020). Systematic review of COVID-19 in children shows milder cases and a better prognosis than adults. Acta Paediatrica, International Journal of Paediatrics, 0-3. https://doi.org/10.1111/apa.15270

Muhammad Fu'ad Abdul. (2010). Buku Kumpulan Hadits Shahih Bukhari Dan Muslim. Jawa Tengah: Insan Kamil.

Montessori, Maria. (2013). Metode Montessori. Ed: Gerald Lee Gutek. Yogyakarta: Pustaka Pelajar. 
Rosyida Nurul Anwar, Nurul Azizah

Padjirin. (2016). Pola Asuh Anak dalam Perspektif Pendidikan Islam. Intelektualita, $5,1-14$.

Setiawan, S. (2017). Pengaruh Bentuk Pola Asuh Orang Tua Dan Regulasi Diri Terhadap Disiplin Siswa (SMP 17 Agustus 1945 Samarinda). Ejournal.Psikologi. Isip-Unmul.Ac.Id, 5(2), 310-319.

Sulyandari, Ari. (2019). Pengaruh Gadget pada Perkembangan Anak usia Dini. Thufuli: Jurnal Ilmiah pendidikan Anak usia Dini. 1(1). http://riset.unisma.ac.id/index.php/thufuli/article/view/2712/2591

Tirto.id. (2020). Arti New Normal Indonesia: Tatanan Baru Beradaptasi dengan COVID-19. https://tirto.id/fDB3. 